\title{
Article
}

\section{Revisiting the CareerEDGE model of graduate employability}

Dacre-Pool, Lorraine

Available at https://clok.uclan.ac.uk/33178/

Dacre-Pool, Lorraine orcid iconORCID: 0000-0003-2049-8670 (2020) Revisiting the CareerEDGE model of graduate employability. Journal of the National Institute for Career Education and Counselling, 44 (1). pp. 51-56. ISSN 20461348

It is advisable to refer to the publisher's version if you intend to cite from the work. 10.20856/jnicec.4408

For more information about UCLan's research in this area go to

http://www.uclan.ac.uk/researchgroups/ and search for < name of research Group>.

For information about Research generally at UCLan please go to http://www.uclan.ac.uk/research/

All outputs in CLoK are protected by Intellectual Property Rights law, including Copyright law. Copyright, IPR and Moral Rights for the works on this site are retained by the individual authors and/or other copyright owners. Terms and conditions for use of this material are defined in the policies page.

\section{CLoK}

Central Lancashire online Knowledge www.clok.uclan.ac.uk

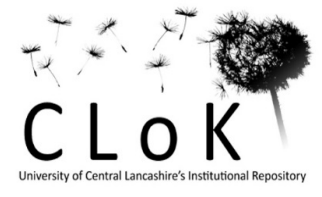




\section{National Institute for Career Education and Counselling}

April 2020, Issue 44

\section{GUIDELINES FOR CONTRIBUTORS}

Manuscripts are welcomed focusing on any form of scholarship that can be related to the NICEC Statement. This could include, but is not confined to, papers focused on policy, theory-building, professional ethics, values, reflexivity, innovative practice, management issues and/or empirical research. Articles for the journal should be accessible and stimulating to an interested and wide readership across all areas of career development work. Innovative, analytical and/or evaluative contributions from both experienced contributors and first-time writers are welcomed. Main articles should normally be 3,000 to 3,500 words in length and should be submitted to one of the co-editors by email. Articles longer than 3,500 words can also be accepted by agreement. Shorter papers, opinion pieces or letters are also welcomed for the occasional 'debate' section. Please contact the relevant issue co-editor(s) prior to submission to discuss the appropriateness of the proposed article and to receive a copy of the NICEC style guidelines. Final decisions on inclusion are made following full manuscript submission and a process of peer review.

\section{SUBSCRIPTION AND MEMBERSHIP}

The journal is published in partnership with the CDI twice a year and is available both in print and online (Print ISSN 2046-I348; Online ISSN 2059-4879). Institutional subscription (online only) costs: $€ 120$ (plus VAT where applicable). Annual print subscription costs $£ 30$ UK, $£ 35$ Europe outside UK or $€ 40$ outside Europe, including postage. Individual online subscription costs $£ 25$ (plus VAT where applicable).

Membership of NICEC is also available ( $£ 75$ pa or $£ 50 \mathrm{pa}$ for full-time students). Members receive the journal, free attendance at NICEC events and other benefits.

For information on journal subscription or membership, please contact:membership@nicec.org

\section{COPYRIGHT AND DISCLAIMER}

Articles are accepted on the condition that authors assign copyright or licence the publication rights in their articles to the National Institute for Career Education and Counselling (NICEC). An important goal of NICEC is to encourage freedom of expression. Individual viewpoints expressed in the journal do not represent NICEC as a whole.

\section{PUBLISHER}

The Journal of the National Institute for Career Education and Counselling is published in partnership with the CDI by: National Institute for Career Education and Counselling (NICEC), The Lodge, Cheerbrook Road,Willaston, Nantwich CW5 7EN.

www.nicec.org

\section{Contents}

\section{EDITORTAL}

2 Overview and introduction | Covid-19, career guidance and the importance of decent work

Fiona Christie, Eileen Cunningham, and Kath Houston

\section{ARTICLES}

5 Trade unions and career services: Potential partners for promoting social justice at work

\section{Peter J. Robertson, Nick Cimini, Jouke Post, and James Corry}

13 Change it up, change the system! Exploring career development learning and social justice through action research

\section{Anne Delauzun}

21 'He who is silent is taken to agree': University careers services and the problem of unpaid graduate internships

\section{Helen Buzdugan}

29 Place-Identity in boundaryless careers: Narratives of medical students from lower socio-economic class backgrounds

\section{Emily Róisín Reid}

36 Maintaining the promise without killing the dream: Developing resilience for future 'graduate' careers

\section{Tracy Scurry, Ciaran Burke, John Blenkinsopp, and Ann Smart}

44 Responding to career uncertainty: Applying a dual-empathy' approach to career development using corporate strategy theory

\section{Naeema Pasha}

51 Revisiting the CareerEDGE model of graduate employability

\section{Lorraine Dacre Pool}

57 Expectation and interaction: Student and employer approaches to university careers fairs

\section{Jodie Boyd and Stephen Boyd}

\section{NEWS}

64 Book review

66 Call for papers | Forthcoming events 


\section{Overview and introduction}

Welcome to the April 2020 edition of the NICEC journal. We are grateful to have had the opportunity to be guest editors.

In planning our call for this edition, we aimed to prioritise certain broad themes. We were interested in research that addresses issues about decent work and uncertain labour markets. We also asked for articles that use theory and research to inform career development policy and practice.

The eight articles published in this edition span a range of topics, all of which align to our themes in various ways. Unsurprisingly perhaps, due to who we are as editors (we all work in universities with backgrounds as careers practitioners), many of the articles relate to career development policy and practice in higher education.

Decent work has been present in the international arena for two decades primarily driven by the International Labour Organisation (ILO). Social justice, full employment and decent work now figure expressly in the United Nations (UN) 2030 Agenda for Sustainable Development. However, it is a concept that has largely been absent from career development policy, practice or scholarship. Decent work has represented an ambitious international agenda, but one which raises questions for many people. Blustein (2019) in the book reviewed in this journal highlights some of the shortcomings of the decent work policy agenda, specifically around its lack of emphasis on work that has meaning and purpose. Hooley (2019) has also warned that however attractive decent work may seem, it is wise for career development specialists to be wary of aligning themselves too closely to specific public policy instruments.

In 2019, a major new ILO report was published that made specific recommendations about decent work. Much of what proponents of decent work argue for aligns with career development priorities, e.g., a universal entitlement to lifelong learning, and supporting people through future of work transitions. Wider issues of social/public policy that are key to decent work have tended to be a lower priority for careers practitioners, although the recent re-direction towards social justice in career guidance, makes the case that practitioners should re-orient their attention to structural issues and be agents of change.

In this edition Robertson et al. explicitly address the role of trade unions as key advocates of work, being pivotal in creating social dialogue and giving voice to workers, an important component of decent work. He and his co-authors explore case studies of how careers workers and trade unions can work together fruitfully.

Articles from Buzdugan and Delauzun address the dilemmas faced by practitioners in supporting more ethical and critical approaches to career development pedagogy and advice and guidance. Effectively, they challenge readers to consider how we support clients and others to engage critically with features of work that may not be decent!

We also asked for articles that address uncertain labour markets and unstable public policy contexts. There have been rapid changes across the globe in the world of work with far-reaching impacts, even for the students and graduates of UK universities who are the focus of attention for many of our authors. We are experiencing the advance of technology in changing work, as well as growing inequalities in labour markets and society, and fears of the halting of intergenerational mobility, not to mention continued economic and political uncertainty.

A number of articles address issues of uncertainty. Reid's, and Scurry et al.'s articles are sociologically oriented. They address inequalities and what these mean for careers practitioners. Reid reports on her work with the elite occupation of medicine, Scurry et al. write about their research with practitioners in understanding the role of graduate resilience. Pasha addresses uncertainty but draws from organisational studies literature, interestingly presenting the concept of career dynamism that she developed in her recent doctoral studies.

Finally, our call was open to authors who weave theory and research into practice. Dacre Pool provides a 
reflective update upon the CareerEDGE model of employability in higher education that will be welcome to those famiiar with or new to the model. This has been an influential model in the graduate employability literature, and draws upon a different theoretical tradition to that of career development, although addressing similar topics. Boyd and Boyd's article introduces us to findings from recent doctoral work into careers fairs, creating new insights into a feature of career development practice that has endured for decades.

In conclusion, we offer you a 'smorgasbord' of articles that we hope will make you stop and think and inform your future practice. As editors, we resist being jaded about the way things are and believe that openness to dialogue, rigorous research and diverse viewpoints can make a real impact on our own practice and prompt us all to re-connect with our values and purpose. We hope that we fulfil this commitment in our selection of articles.

\section{References}

Blustein, D. (2019). The importance of work in an age of uncertainty. Oxford: Oxford University Press.

Hooley, T. (2019). Should decent work be an aim of career guidance? Retrieved from https:// adventuresincareerdevelopment.wordpress. com/2019/1 I/I3/should-decent-work-be-an-aim-ofcareer-guidance/

ILO. (2019). Work for brighter future. Geneva. Retrieved from: https://www.ilo.org/global/topics/future-of-work/ brighter-future/lang--en/index.htm

\section{Covid-19, career guidance and the importance of decent work}

The Covid-19 pandemic emerged at the same time as we prepared for final publication of this edition of the journal. Our themes of decent work and uncertainty have been amplified by the crisis to an extent we could never have imagined possible. The extraordinary nature of this global pandemic compelled us to want to include some thoughts about Covid-19, career guidance and decent work. We write here about it from our English context, but expect our comments may be relevant to readers in other nations.

It is too early to know for sure how Covid-19 will affect work and careers. We must recognise the gravity of what the current situation means for working lives, but also resist doom-mongering that risks creating its own self-fulfilling prophecy. Commentators from within and outside our field have already begun to debate causes of and responses to the spreading of the virus. The UN's environment chief, Inger Andersen (Carrington, 2020) points to environmental degradation as being a direct cause of its emergence. Hooley, Sultana and Thomsen (2020) argue that many capitalist societies with their focus on economics and market principles are ill-prepared for a health emergency which needs strong social safety nets to protect workers and citizens.

In the UK, we have witnessed some heartening responses to the virus that relate to work. Suddenly it became important to determine the definition of a 'key worker', which has made us all reflect upon the importance of many workers we usually take for granted. For example, low-waged supermarket staff and delivery drivers have been recognised as having an essential status alongside nurses and doctors. However, more negatively, the political legacy of the BREXIT policy means there are shortages of 'key workers', e.g., social carers and agricultural workers.

The profound connection between each of us and our local communities, our nation and the rest of the world is impossible to ignore. The virus rides on the coat tails of globalisation and has been carried across the world with international travellers. Margaret Thatcher's claim that there is 'no such thing as society' has been exposed 
as absurd. The virus demands a collective and societal response. The Covid-19 pandemic has led to the collision of our lives as workers, as citizens and as family members (or equivalent).We have experienced this as editors; while working to finalise this journal, we have separately been dealing with home-schooling children, caring for very vulnerable relatives, and managing our own anxieties. We all hold multiple identities and it seems ridiculous to ignore how these are interconnected. More generally, this exposes the fault lines in assumptions about people as rational career actors. The current crisis has highlighted the impossibility of seeing work as anything other than profoundly connected to our lives as a whole.

Uncertainty will be a very real feature of working lives for many people because of the virus. Some will lose their jobs; some businesses even with government support may never re-open. The incomes of particular groups, e.g. selfemployed workers appear particularly at risk. A concern for us as editors working in higher education is the challenge the post-virus world will represent for those who are just starting out in their careers. Many of those in more secure work will have work rapidly transformed, as practices such as travelling long distances for face-toface meetings will be questioned, as workers get more accustomed to technology.

The principles of decent work can help society re-build and recover from this crisis. Those principles are: creating productive and freely chosen work; protecting rights at work; ensuring social protection for workers; and enabling social dialogue between workers and employers. Such ideas can help us move forwards in a world that will never be the same after this crisis. Career guidance can play an important part in supporting these principles.

Career practitioners will be crucial in helping individuals to navigate the uncertainty that will follow the Covid-19 crisis. The establishment of a universal right for all citizens to access careers advice and guidance would help workers in managing careers that have been derailed and disrupted. This advice can include everything from the practicalities of self-employment, to coping with redundancy, as well as making career decisions and all aspects of career management. The recent turn to careers guidance for social justice is timely in arguing that career practitioners should be agents of change in pointing out unfairness and advocating for the most vulnerable. It is not enough for us to default to a focus on helping people to compete with each other for a few sought after jobs. We should be arguing for there to be decent and meaningful work for all, not just the lucky few who may have the resources to surf the Covid- 19 tidal wave.

\section{References}

Carrington, D. (2020). Coronavirus: 'Nature is sending us a message', says UN environment chief. Retrieved from https://www.theguardian.com/world/2020/mar/25/ coronavirus-nature-is-sending-us-a-message-says-unenvironment-chief

Hooley, T., Thomsen, R., \& Sultana, R. (2020). Why a social justice informed approach to career guidance matters in the time of coronavirus. Retrieved from https:// careerguidancesocialjustice.wordpress.com/2020/03/23/ why-a-social-justice-informed-approach-to-careerguidance-matters-in-the-time-of-coronavirus/

\section{For correspondence}

\author{
Fiona Christie \\ Senior research associate, Decent Work and \\ Productivity Research Centre, Manchester \\ Metropolitan University \\ f.christie@mmu.ac.uk
}

Eileen Cunningham

Social Policy lecturer, University of Salford

E.A.Cunningham2@salford.ac.uk

Kath Houston

Teaching fellow, Lancaster University

kmhoustl@gmail.com

Fiona Christie, Eileen Cunningham \& Kath Houston, Editors 


\section{Revisiting the CareerEDGE model of graduate employability}

\section{Lorraine Dacre Pool}

It has been thirteen years since the publication of the article that introduced the CareerEDGE model of graduate employability. During this time, there have been many changes in Higher Education and the graduate employment market, which raises the question, is the CareerEDGE model still relevant in 2020? This article looks back at the development of the model and the complementary questionnaire, the Employability Development Profile and evaluates their global impact. It also considers any criticisms and explores some other employability-related concepts for inclusion in a model of graduate employability development.

\section{Introduction}

It has been thirteen years since the article introducing the CareerEDGE model of graduate employability development (Dacre Pool \& Sewell, 2007) was published in the journal Education + Training. During this time, Higher Education (HE) has experienced rapid change, not least the large increase in student fees in 2012, bringing with it an increasingly consumerist approach to education. One outcome of this is more focussed attention on the student experience, which includes ensuring students have access to development opportunities that help them to increase their chances of success within $\mathrm{HE}$ and to prepare them for life beyond university.

As a psychologist, viewing employability as something the individual can develop and improve, feels positive, empowering and optimistic. The CareerEDGE Model approaches employability from the same perspective as Yorke (2006) who describes it as a multi-faceted characteristic of the individual. Of course, it is essential to recognise that developing employability does not guarantee a graduate a satisfying occupation. For example, Clarke (2008) draws attention to the fact that '...even the most seemingly employable person may experience difficulty finding a suitable job in an unsympathetic labour market.' (p. 269). However, labour market conditions and other external factors are not something that we as employability developers can influence, but we can try to ensure our students are made aware of them. As De Cuyper et al. (201I) point out, the word 'employability' is derived from the words 'employment' and 'ability'. Universities may be able to influence the 'ability' element which refers to the person's skills and competencies but have no control over the 'employment' aspects which are dependent on a number of issues, including labour market demand.

With all of this in mind, now seems like an opportune time to revisit CareerEDGE and consider if it still has value and relevance in 2020 .

\section{Development of the CareerEDGE model}

The article that introduced CareerEDGE was the result of in-depth, rigorous research into the concept of graduate employability, which had revealed the concept as somewhat woolly and often misunderstood. In particular, from much of the literature on the subject, it was very difficult to distinguish the difference between employability and career management/development learning (CDL). A 'lightbulb moment' occurred when it became clear that $\mathrm{CDL}$ was just one aspect of employability development and that seeing them as interchangeable concepts 


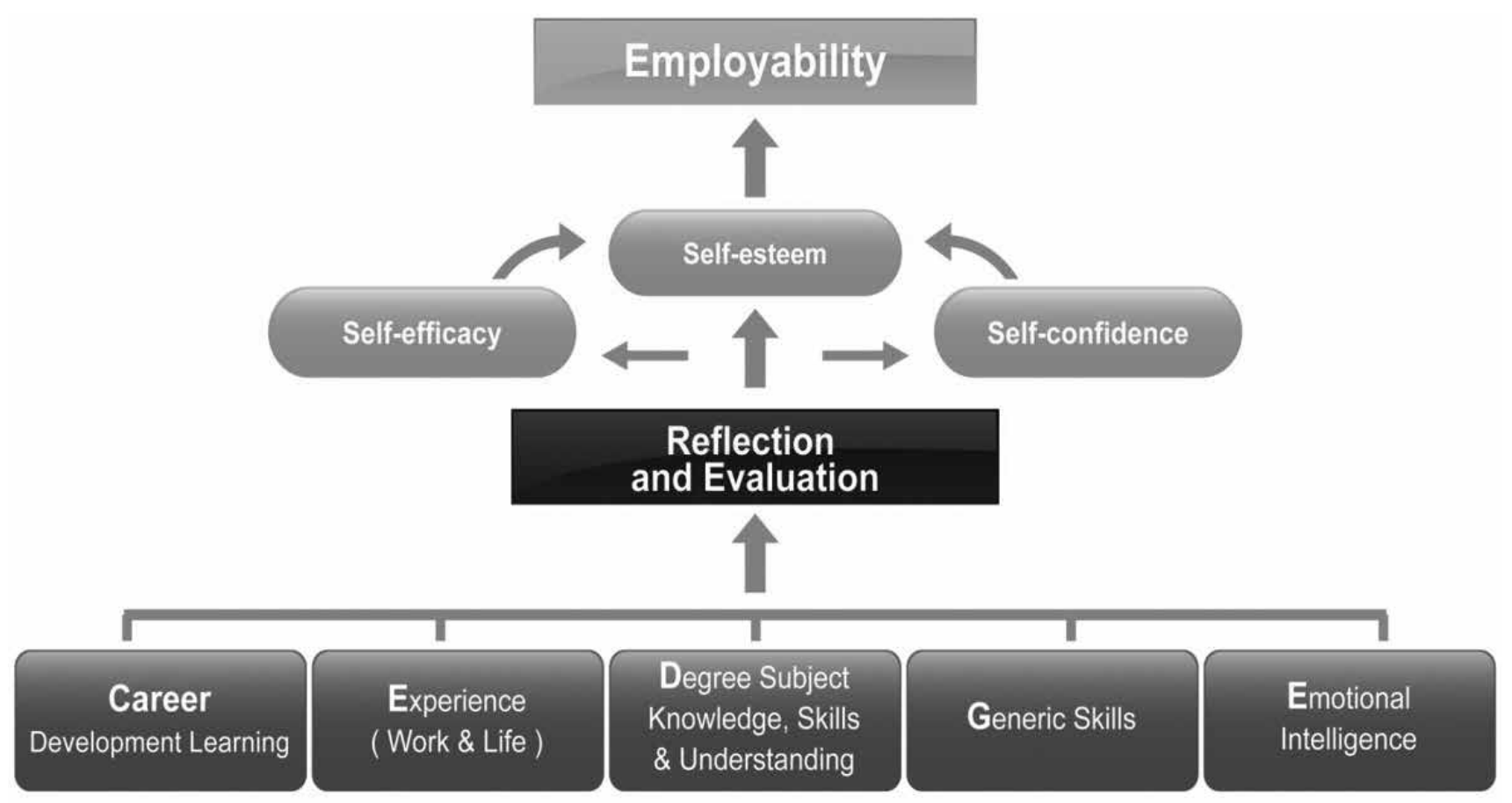

Dacre Pool \& Sewell (2007)

was one of the reasons why people were mistakenly viewing employability development as exclusively CVs, applications and other job-getting activities (which are themselves, tools to support just one aspect of $\mathrm{CDL}$ ). Once this was established, the rest of the essential elements of CareerEDGE became clearer. It is vital that in addition to $C D L$, students are given opportunities to gain real-world experience, develop their generic skills and their emotional intelligence (EI). At the centre of CareerEDGE is the ' $D$ ' for degree subject knowledge, skills and understanding. One of the reasons for the success of the model has been this emphasis on the degree subject being at the centre of the student's experience and, in itself, an essential element of employability development.

\section{Career Development Learning, Experience (Work \& Life) and Generic Skills}

Career Development Learning $(\mathrm{CDL})$ is indeed about ensuring students are well prepared for job applications and interviews, but a good deal of important work in this area takes place long before graduation. Developing self-awareness, which is essential for a successful life beyond university, together with guidance on the wide-range of opportunities open to graduates, are also key to helping students make career decisions that ensure they stand the best chance of securing and retaining occupations they will find satisfying and fulfilling. Additionally, students now need support with presenting themselves in digital spaces such as Linkedln or other social media and preparing for modern-day selection processes, such as video interviews. CDL activities can also help students to explore important aspects of future careers such as the increasing use of artificial intelligence in the workplace and the importance of living and working in sustainable ways.

Experience, from paid and voluntary work, is also essential. It not only allows students to develop many of the generic skills employers look for in graduate recruits, for example the ability to communicate with different people, work as part of a team and solve problems, but can be another helpful way of learning about what they are looking for and importantly, what they do not enjoy, in an occupation. 


\section{Emotional Intelligence}

Before the original publication I was concerned that the inclusion of El in a model of graduate employability development would be met with some criticism from the academic community but fortunately this did not happen. In fact, quite the opposite occurred with many academic colleagues agreeing that $\mathrm{El}$ is an essential element of employability development. This is supported by the fact that many employers now include $\mathrm{El}$ in job descriptions and person specifications. In 2015, the Chief Assessor and Chief Psychologist with responsibility for recruiting individuals to the Civil Service Fast Stream graduate programme was quoted as saying 'We want people with good interpersonal skills, emotional intelligence...' (Leach, 2015). El also features as part of the Civil Service Learning curriculum, which demonstrates its acceptance as an important aspect of everyday experience in the workplace. Having asserted that El was a key aspect of employability development, I needed to be able to demonstrate that it was possible to teach and for students to develop. This work was carried out between 2007 and $201 \mathrm{I}$ and provided evidence to support this assertion, not only demonstrating that El could be taught but that students can also develop confidence in their El ability, otherwise known as Emotional Self-Efficacy (Dacre Pool \& Qualter, 2012). Confidence in any ability means there is a greater chance that it will be used. If we needed any further convincing, a recent meta-analysis has shown a clear, positive association between $\mathrm{El}$ and academic performance and supports the growing consensus among educators, researchers and policy makers, of its importance for both wellbeing and future workplace success of students (MacCann et al. 2020).

\section{Cultural Intelligence}

One further concept that does warrant explicit inclusion within CareerEDGE is Cultural Intelligence. This concept shares a degree of overlap and interaction with $\mathrm{El}$, and some researchers now consider it to be a key part of the concept (Mayer, Caruso \& Salovey, 2016). Cultural Intelligence is defined as 'an individual's capability to function and manage effectively in culturally diverse settings' (Ang \& Van Dyne, 2009, p3) and is an essential skill in today's diverse workplaces and global society.

\section{Reflection and Evaluation}

At the next level of the model, we have 'Reflection and Evaluation', whereby students should be provided with guidance and opportunities to reflect on and evaluate their employability learning experiences. Reflective logs, diaries, portfolios and journals have become widely accepted assessment activities across the HE sector, with a recognition that it is often guided reflection on learning experiences that allows effective and deep learning to take place (Artess, Hooley \& Mellors-Bourne, 2017). It is these deep learning experiences that have the potential to bring about increases in Self-Efficacy, Self-Confidence and Self-Esteem (the three Ss), so vital for employability development.

By engaging with all the elements of the model, graduates have a better chance of reaching their full potential and developing their personal resilience. For example, a student may take part in an in-class activity where they are given a group problem-solving task. During the activity they may find themselves naturally assuming a leadership role, encouraging quieter members of the group to contribute, organising the different members with essential tasks and managing the time, resulting in a positive outcome for their group. Time spent reflecting on this activity should allow the student to recognise the different generic skills they were able to develop and demonstrate during the activity. They may also recognise their $\mathrm{El}$ ability, which helped them to see when others may have wanted to contribute but didn't feel able to (reading emotions in others), recognise and regulate their own emotions (they may have felt anxious about completing the task but worked through this with the resultant successful outcome). We can see how taking part in this planned classroom activity and reflecting on it, could lead to this student recognising that they do have potential for a leadership role, should they choose to follow this path in the future.

\section{Resilience - connected to the three Ss and EI}

The subject of resilience is receiving a good deal of attention in $\mathrm{HE}$, with growing concern about students struggling to cope and experiencing mental health 
issues. Resilience was not explicitly included in the original CareerEDGE model but is closely related to the three Ss and to El. For example, a student who takes part in a work-related experience, perhaps a project working to a brief from an employer, will no doubt experience set-backs and challenges along the way. Perhaps they will make a mistake. By reflecting on this experience and being guided to learn from it, they can also see that mistakes are part of life - we learn from them and use the learning in future. It is this type of experience that helps to build self-efficacy, self-confidence, self-esteem and resilience and can be recalled to mind when similar challenges are faced in the future. Additionally, developing aspects of El such as emotion regulation strategies, will also be helpful for building resilience.

\section{Other related-concepts for consideration}

Over the years there have been a number of other suggestions for inclusion in a model of graduate employability development. These include concepts such as positive attitude, integrity, enthusiasm and other aspects of good character. These, among others, can be recognised as important for any student to develop, but unlike other aspects of CareerEDGE, they cannot be taught in the same way we can teach knowledge, skills and abilities. However, as part of CDL activities, we can and should talk to our students about them, explain their importance for future career activities and help them to articulate evidence of them in future job applications and interviews.

\section{The Employability Development Profile (EDP)}

The CareerEDGE Employability Development Profile (EDP) is a brief self-report diagnostic tool that encourages students to consider their employability strengths and plan actions for any improvements. It has been made freely available to the academic community throughout the world and translated by overseas universities into a number of different languages including German, Spanish, Polish, Mandarin and Persian. It is not the answer to everything employability related but can ensure that students recognise early on in their HE experience that employability is not just about getting a job, which can wait until their final year or until after graduation. They are then in a much better position to take advantage of the many learning opportunities on offer whilst they are studying, which will help them to develop their employability throughout their degree studies. It is recommended that students complete the EDP on an annual basis, allowing them to 'check-in' with their employability development and continue to plan their next steps.

The psychometric properties of the EDP have been examined and published (Dacre Pool, Qualter \& Sewell, 2014). More recently, changes have been made to the enterprise/entrepreneurship question on the front of the questionnaire. Where there used to be a statement, 'I would consider starting my own business' with a 'Yes/No' response, following helpful feedback from an expert in this area, this has now been updated to two questions, 'Are you interested in self-employment?' and 'Do you have an idea that might be developed into something of social, cultural or economic value?' A 'Yes' response to either of these questions allows students who may need support with an enterprising idea to be guided towards relevant services.

\section{Further developments}

There is a widespread recognition that providing opportunities for students to develop their employability is an increasingly important aspect of any teaching and learning strategy and CareerEDGE provides a framework for these activities. To support academic colleagues with embedding employability in the curriculum we developed the Course Employability Mapping Tool which allows course teams to audit employability-related activities in their provision, recognise any gaps, and plan actions for improvements. This tool is also freely available to the academic community on request.

\section{Recognition}

The success of CareerEDGE has been somewhat overwhelming, being described as 'the most comprehensive' model of graduate employability (Small, Shacklock \& Marchant, 2018) and a 'sustainable employability model' (Tymon, Harrison \& Batistic, 
2019). Shortly after publication, the article was selected by Emerald as one of ten noteworthy articles (from approximately 450) included in the 'Monthly Highlights' section of their website and then featured weekly as the most downloaded article in the journal for over a decade. At the time of writing, it has been downloaded almost 60,000 times and cited 1088 times (Google Scholar, accessed 25.2.20). It has appeared in journal articles, book chapters, published reports and is used extensively in Careers/Employability Services and academic departments across the HE sector, in the UK and throughout the world, including Europe, the U.S., Australia, North Africa, the Middle East and Far East.

One example of this is the University of South Carolina in the U.S. where the model was slightly adapted and used to write a chapter for a Year I transitions text book. The model was presented to several thousand first year students and their parents during the summer of 2015. At University College Dublin, the model has been used extensively as their chosen employability framework. Careers staff there have mapped their work onto CareerEDGE, illustrating the impact of the entire team.

\section{Using CareerEDGE has allowed staff to} appreciate and assimilate the breadth of what makes a student employable. While the importance of effective CV's and performance across graduate recruitment and selection remains critical, we have a focus on enhancing students' skill development, self-efficacy and selfconfidence. These, we see, as the building blocks for success in life at University and beyond.

(David Foster, UCD Director of Career Development and Skills, 2016)

\section{Value and relevance of CareerEDGE}

People often say that the reason for its success is that the original article is readable, the model perfectly understandable and straightforward to explain to others and to operationalise. There has been very little criticism of the model. Only some unpublished whisperings that it is too simple! However, I would answer this possible criticism with a question; why does it have to be complicated? Complicated doesn't necessarily mean good - in fact it can often hide some very muddled thinking... One senior academic recently wrote in a Times Higher Education article that 'The view seems to have taken hold that serious work must be painful to read, and almost impossible to understand' (Tourish, 2019). Personally, I do not see the point of producing work of this nature that only a tiny percentage of the population will read, and an even tinier percentage understand. I would rather be criticised for simplicity but know the work is of interest and use to many.

Since its original publication in 2007, the CareerEDGE model has informed the way careers practitioners and academic staff understand and teach employability development. The elements on the lower part of the model, are still essential for employability development, as is the assertion that reflection is the key to the development of self-efficacy, selfconfidence and self-esteem. In the current economic climate, with the resultant uncertainty and precarity in the labour market, it is more important than ever that our students are as prepared as they can be to face these future challenges and thrive in this rapidly changing world. The CareerEDGE model supports this endeavour and indeed, in a more marketised $\mathrm{HE}$ sector, helps us to meet the higher expectations of our students in relation to developing their employability (Money, et al. 2017).

Interest and positive feedback in relation to CareerEDGE over the years from both Careers/ Employability professionals and academic colleagues, provides strong evidence for its current relevance and sustainability. Nottingham Trent University were one of the first UK universities to utilise CareerEDGE and it seems pertinent to conclude with the words of their Director of Employability,

As the future of work develops at an even faster pace, we cannot hope to prepare our graduates for jobs which in all likelihood have not yet been invented. However, if our ambition is to equip graduates to be adaptable in a changing world and secure successful and fulfilling futures for themselves, then CareerEDGE is probably more relevant now than it has ever been.

(David Eade, 2019) 


\section{y References}

Ang, S., \& Van Dyne, L. (2009). Conceptualization of Cultural Intelligence. Definition Distinctiveness and Nomological Network. In S.Ang \& L.Van Dyne (Eds.) Handbook of Cultural Intelligence:Theory Measurement and Application, Chapter I. New York: Routledge

Artess, J., Hooley, T., \& Mellors-Bourne, R. (2017). Employability: A review of the literature 2012 to 2016 . York: Higher Education Academy

Civil Service Learning Curriculum. Retrieved from https://civilservicelearning.civilservice.gov.uk/sites/ default/files/resources/curriculumprospectusapr /8.pdf

Clarke, M. (2008). Understanding and managing employability in changing career contexts. Journal of European Industrial Training, 32(4), 258-284. doi: I0.1 108/03090590810871379

Dacre Pool, L. \& Qualter, P. (20I2). Improving emotional intelligence and emotional self-efficacy through a teaching intervention for university students. Learning and Individual Differences, 22, 306-312. doi:10.1016/j.lindif.2012.01.010

Dacre Pool, L., Qualter, P., \& Sewell, P.J. (20I4). Exploring the Factor Structure of the CareerEDGE Employability Development Profile. Education + Training, 56(4), 303-3 I3. doi: I0.I I08/ET-0 I-2013-0009

Dacre Pool, L., \& Sewell, P. (2007). 'The key to employability: developing a practical model of graduate employability'. Education + Training, 49 (4), 277-289. doi: I0.1 108/00400910710754435

De Cuyper, N., Mauno, S., Kinnunen, U., \& Mäkikangas, A. (20I I). The role of job resources in the relation between perceived employability and turnover intention:A prospective two-sample study. Journal of Vocational Behavior, 78, 253-263. doi: 10.1016J. JVB.2010.09.008

Eade, D. (2019). Personal communication, I0th September 2019.

Foster, D. (2016). UCD Career Development Centre, Annual Report, 2015/16. Retrieved from https://www. ucd.ie/t4cms/UCD\%20CDC\%20Annual\%20Report\%20 2016\%20web.pdf

Leach, A. (20I5, September I). How to ace the civil service fast stream assessment centres. The Guardian.

Retrieved from http://www.theguardian.com/publicleaders-network/20I5/sep/0 I/civil-service-fast-streamassessment-centre-whitehall-graduate-scheme MacCann, C., Jiang, Y., Brown, L. E. R., Double, K. S., Bucich, M., \& Minbashian, A. (2020). Emotional intelligence predicts academic performance:A metaanalysis. Psychological Bulletin, I46(2), I50- I86. https:// doi.org/l0.1037/bul00002/9

Mayer, J.D., Caruso, D.R., \& Salovey, P. (2016).

The Ability Model of Emotional Intelligence:

Principles and Updates. Emotion Review, I- I I. doi: I0.1/77/17540739|6639667

Money, J., Nixon, S., Tracy, F., Hennessy, C., Ball., E \& Dinning, T. (2017) Undergraduate student expectations of university in the United Kingdom: What really matters to them?, Cogent Education, 4: I, doi:

$10.1080 / 2331186 \times .2017 .1301855$

Small, L., Shacklock, K., \& Marchant, T. (20l8). Employability:A Contemporary Review for Higher Education Stakeholders. Journal of Vocational Education \& Training, 70(I), I48-I66. doi: I0.1080/13636820.20 I7.I 394355

Tourish, D. (2019). Do business schools still have brand value? Times Higher Education. Retrieved from https:// www.timeshighereducation.com/features/do-businessschools-still-have-brand-value

Tymon, A., Harrison, C., \& Batistic, S. (2019).

Sustainable graduate employability: an evaluation of 'brand me' presentations as a method for developing self-confidence. Studies in Higher Education, doi:

10.1080/03075079.2019.1602757

Yorke, M. (2006). Employability in higher education: what it is - what it is not.April 2006. York:The Higher Education Academy

\section{For correspondence}

Dr. Lorraine Dacre Pool, PhD, CPsychol

Principal Lecturer, Student \& Staff Development,

Centre for Collaborative Learning,

University of Central Lancashire

Idacre-pool@uclan.ac.uk 